\title{
Sustainability impacts of ecosystem approaches to small-scale aquaculture in Bangladesh
}

\author{
Rodolfo Dam Lam ${ }^{1,3}$ - Benoy Kumar Barman ${ }^{2} \cdot$ Denise P. Lozano Lazo ${ }^{1} \cdot$ Zohura Khatun $^{2} \cdot$ Lutfa Parvin $^{2}$. \\ Afrina Choudhury ${ }^{2}$. Cristiano M. Rossignoli ${ }^{3} \cdot$ Alice Karanja $^{4}$ - Alexandros Gasparatos ${ }^{4,5}$
}

Received: 23 September 2020 / Accepted: 14 November 2021 / Published online: 1 January 2022

(c) The Author(s) 2021

\begin{abstract}
This study explores the sustainability impacts of adopting an ecosystem approach in underutilized homestead ponds (ecoponds) operated by women in Bangladesh. Households with ecoponds have significantly higher fish productivity, fish diversity, and income generation potential compared to households with similar underutilized ponds. Furthermore, certain dimensions of women's empowerment are improved at the individual and household level (e.g., control of income and productive assets), without, however, addressing wider structural inequalities. Food security impacts are rather inconclusive, as despite the higher consumption of more diverse fish species among ecopond households, there is no significant effect on overall dietary diversity.
\end{abstract}

Keywords Food security $\cdot$ Women's empowerment $\cdot$ Rural livelihoods $\cdot$ Income $\cdot$ Fish productivity $\cdot$ Fish diversity

\section{Introduction}

The demand for animal protein (including fish) has been increasing globally in the past decades (Cao and Li 2013; Kastner et al. 2012; FAOSTAT 2020). Depending on the geographical context, different factors, such as population growth and changes in dietary preferences, have driven this increase (Alexander et al. 2015; Kastner et al. 2012; Weindl et al. 2017). However, this increase has been largely linked to negative environmental impacts. For example, the expansion and transformation of terrestrial livestock production systems have been linked to extensive land use change,

Handled by Laura Pereira, Stockholms Universitet, Stockholm Resilience Centre, Sweden.

Rodolfo Dam Lam

rdamlam@gmail.com

1 GPSS-GLI, University of Tokyo, 5-1-5 Kashiwanoha, Kashiwa, Chiba 277-0882, Japan

2 WorldFish, Dhaka, Bangladesh

3 WorldFish, Penang, Malaysia

4 Institute for Future Initiatives (IFI), University of Tokyo, Tokyo, Japan

5 Institute for the Advanced Study of Sustainability (UNU-IAS), United Nations University, Tokyo, Japan ecosystem degradation, greenhouse gases (GHG) emission, pollution, and biodiversity loss (IPBES 2019). The combined effects of increased fish demand with unplanned aquaculture and unregulated fishery practices have been linked to fisheries overexploitation, ecosystem degradation, and pollution (Amirkolaie, 2011; Merino et al. 2012; Henriksson et al. 2018).

Several studies have suggested that decreases in the demand and supply of some types of animal protein, especially meat, can have major environmental benefits (Hartmann and Siegrist 2017; Henchion et al. 2017). Yet, in some parts of the developing world, there is a real need to expand the supply and consumption of animal protein to improve household nutrition and enhance food security (Béné et al. 2015; Beveridge et al. 2013). However, the expansion of some conventional livestock systems is not always feasible or desirable due to various production constraints (e.g. land/ water scarcity) and cultural reasons (e.g. religious sensibilities) (Nam et al. 2010; Weindl et al. 2017). In fact, the rapid current population increase and improvement in economic conditions could also catalyse a rapid increase in animal protein demand in many developing countries (Henchion et al. 2017).

Despite some challenges, aquaculture is a possible avenue to meet some of this increasing animal protein demand in a sustainable manner (Hua et al. 2019). Studies have pointed 
that in some developing contexts, small-scale aquaculture systems have a huge potential to provide animal protein in an environmentally sustainable, and socially and culturally appropriate manner (Ross et al. 2008; Subasinghe et al. 2009; Thilsted et al. 2016). For example, some small-scale aquaculture systems have been linked to various positive socioeconomic impacts linked to livelihoods (Ross et al. 2008; Toufique and Belton 2014), food security (Ahmed and Lorica 2002; Béné et al. 2016) and some level of women's empowerment (Farquhar et al. 2019; Choo and Williams 2014). However, such aquaculture systems face constraints related to access to knowledge, credit, or inputs (Henriksson et al. 2017; Cole et al. 2020), or the inclusive engagement in terms of gender, wealth, or age, among others (Diedrich et al. 2019; Harohau et al. 2020; Kruijssen et al. 2018).

Bangladesh is one of the developing countries where small-scale aquaculture already plays a major role for the livelihoods and food security of a large fraction of the population (Hernandez et al. 2018; Jahan et al. 2010; Siddiqua et al. 2017). Both public and private organizations have strongly promoted aquaculture in an attempt to meet fish demand. With an annual production of about 2.4 million tonnes of cultured fish, Bangladesh ranked in 2018 as the world's fifth-largest inland aquaculture producer (FAO 2020). In 2018-2019, aquaculture accounted for $56.76 \%$ of the total national fish production (for comparison, inland capture fisheries contributed $28.19 \%$ ), reflecting a $134 \%$ increase compared to 2008-09 levels (1.06 million tonnes) (DoF 2019). Average aquaculture yields range varies between systems: from $4.96 \mathrm{t} / \mathrm{ha}$ for ponds, $1.50 \mathrm{t} / \mathrm{ha}$ seasonal waterbodies, $1.82 \mathrm{t} / \mathrm{ha}$ baors (oxbow lakes), and 0.99 t/ha for shrimp ghers ${ }^{1}$ (DoF 2019). Even though some of the aquaculture output is exported (73.1 thousand tonnes in 2018-2019), most is consumed nationally (DoF 2019).

When it comes to the main production approaches, aquaculture production systems in Bangladesh are mainly semi-intensive and intensive (Belton and Azad 2012; Hossain 2015). Inland ponds are the mainstay of Bangladesh's aquaculture sector, accounting for around $80 \%$ of the total aquaculture output and are presently dominated by carp (indigenous and exotic), pangasius, and tilapia species (DoF 2019). Roughly 4.27 million households (20\% of the rural population) operate at least one homestead pond, which are typically small in size (0.08-0.1 ha on average). This small size reflects land scarcity, high construction costs, and the fact that the ponds have multiple domestic uses, such

\footnotetext{
${ }^{1}$ Ghers in Bangladesh are traditional agriculture system consisting of modified rice fields use for fish farming where a pond is dug into the rice field and the dug out soil is used to create high, broad peripheral dykes around the pond for growing vegetables (Morgan et al. 2015; McDougall 2017).
}

as washing, bathing, and cooking (Belton and Azad 2012). Usually small homestead ponds cater to household food needs, but commercial production is increasing for some (or all) of a household's aquaculture output (Belton and Azad 2012; Choudhury et al. 2017).

The aquaculture sector has considerable socioeconomic impacts in the country, considering its scale and extent. For example, the sector contributes substantially to income generation and poverty alleviation (Azad et al. 2009; Siddiqua et al. 2017). Furthermore, it contributes to food and nutritional security, as $60 \%$ of the animal protein intake in the country is obtained from aquatic animals (FAO 2016; Toufique and Belton 2014). As a result, the average annual per capita fish consumption in Bangladesh is higher compared to the global average (FAO 2020). However, Bangladesh's aquaculture sector has also been linked with various sustainability challenges, such as the degradation and pollution of water bodies, low-value addition, and constraints in farmers' access to good-quality input (e.g. high-quality seed of improved fish strains, high-quality feed) (Ghose 2014; Nabi 2008). There are also major discrepancies between social groups in terms of fish consumption, with poorer families, women and children consuming less fish per capita than the national average (Beveridge et al. 2013; Mostafa et al. 2008).

Women play a significant role in Bangladesh's aquaculture sector. When it comes to employment, the official statistics report that 1.4 million of women (out of 17.8 million employed women) are occupied in the aquaculture and fisheries sectors (FAO 2017). However, other studies have estimated a much larger proportion of women engaged in certain aquaculture activities. For instance, women account for $>80 \%$ of the labor force in fish processing companies (Shamsuzzaman et al. 2017), and $>50 \%$ of casual laborers in fish drying sites (Belton et al 2017). However, despite their large share of employment in the aquaculture sector, the actual benefits for women are questionable or not adequately assessed. For example, while the extensive employment of women in the fish industry is seen as a positive indication for women's empowerment (Gopal 2014), the fact remains that women are mostly employed in lower level jobs and their role remains largely underreported in national statistics (Ahmed et al. 2012; Halim and Ahmed 2006; Shelly and D'Costa 2001).

When it comes to homestead aquaculture production, women account for up to $22 \%$ of the total labor (Jahan et al 2015). Indeed, it is estimated that approximately $43 \%$ of rural women dedicate some of their time to homestead aquaculture (Halim and Ahmed 2006). Thus, it has been perceived as a fertile ground to empower women. The research and development foci for women in the aquaculture-agricultural sector in Bangladesh have been largely confined to such homestead systems, which are perceived as a convenient domain that can "accommodate" women's mobility and 
access issues (Aregu et al. 2018; Choudhury et al. 2017; Farnworth et al. 2016). However, attaining women's empowerment through aquaculture innovations through homestead pond system has also been challenging, with most interventions enabling empowerment only at the welfare and access levels (Choo and Williams 2014). This has often left other key elements of empowerment, such as the control over pond or income, and the ability to make important life choices either unattained or with incremental changes (Choudhury et al 2017). This has pointed towards the structural inequalities that gender norms and power relations present in rural Bangladesh. However, it has also shown that it is challenging to achieve all dimensions of women's empowerment simply through inclusion in homestead aquaculture innovations (Choudhury et al. 2017).

The sustainable intensification ${ }^{2}$ of small-scale aquaculture systems in Bangladesh offers a huge opportunity for curbing some of the sector's negative environmental impacts, while enhancing socioeconomic benefits associated with pond productivity, food security, rural livelihoods, and women's empowerment (Azad et al. 2009; Belton and Thilsted 2014; Jahan et al. 2010, FAO 2010). As a result, various innovations have been geared towards improving the performance of small-scale aquaculture systems in the country (Jahan et al. 2015).

One promising innovation has been the ecopond model, which has sought to enhance fish production and pond productivity by empowering women to employ ecosystem approaches to aquaculture in underutilized homestead ponds (WorldFish 2017). Ecosystem approaches to aquaculture encompass diverse strategies that consider ecosystem functions and services (and avoid compromising their sustained delivery), improving in the process human wellbeing and equity for all relevant stakeholders (Brugère et al. 2019; FAO 2010). In the ecoponds models, the ecosystem approach relates to the improvement of fish habitat through the use of readily available natural materials (e.g. aquatic vegetation, coconut leaves, bamboo tubes/branches), whose potential is further leveraged by the iterative training of women on how to develop, manage and effectively use the ponds and produced fish (WorldFish 2017). It was hypothesized that such "ecoponds" that combine ecosystem approaches to aquaculture in underutilized ponds, with capacity-building for women, can have multiple ripple positive impacts for

\footnotetext{
${ }^{2}$ Sustainable intensification seeks to increase aquaculture production, while limiting adverse environmental impacts (Henrikson et al. 2018; Ellis et al. 2016). For small-scale aquaculture and fisheries systems, studies have found that practices, such as improved harvest strategies, disease management, and waste reduction, among others, can increase production efficiency and help achieve sustainable intensification goals (Engle et al. 2017; Haque et al. 2016; Henriksson et al. 2018 Joffre et al. 2018)
}

livelihoods, food security, and some dimensions of women's empowerment (refer to the Methodology for a delineation of the women's empowerment aspects of the ecoponds model).

The aim of this study is to assess through an interdisciplinary mixed-method approach the major sustainability impacts (and specific pathways to impact) of the "ecoponds" production model. The Methodology section outlines the (a) analytical framework and the pathways mediating ecoponds' impacts, (b) the women's empowerment aspects of the ecoponds model (c) study sites and groups, (d) data collection and analysis methods. The Results section highlights the impacts of ecoponds on fish productivity, household income, food security, and dimensions of women's empowerment, comparing different treatment groups (i.e. ecopond users) and their respective control groups. The Discussion section critically synthesizes the main findings and offers recommendations on how to further improve the sustainability performance of ecosystem approaches to small-scale aquaculture.

\section{Methodology}

\section{Research approach}

\section{Ecoponds intervention}

The ecoponds model is essentially a user-oriented sustainability solution. The model seeks to maximize in a costeffective manner the potential of small and underutilized homestead ponds for women-led small-scale fish production, predominately for subsistence and secondarily for market selling (WorldFish 2017).

These ponds are smaller in size $\left(250-500 \mathrm{~m}^{2}\right)$ than average household ponds and are not originally destined for fish production but are often the remains of digging operations for housing, agriculture or infrastructure (e.g. ditches). The ponds can be seasonal (i.e. completely dry up during lowrainfall months) or perennial (i.e. hold water throughout the year). Even though some of these ponds are used for fish production using extensive management approaches, this is usually the exception, with the actual productivity being very low (usually $<500 \mathrm{~kg} / \mathrm{ha}$ ) (WorldFish 2017).

The ecopond approach was conceived during preliminary participatory action research with about 60 women and 60 ponds, in four communities located in two polders in Khulna District. This early work highlighted that readily available natural habitat elements, such as bamboo branches, roots, and aquatic vegetation, can offer a good shelter and source of natural food for many different fish species, and thus increase fish diversity and overall pond productivity (Kabir et al. 2015; WorldFish 2017). These preliminary observations suggested that this simple and affordable ecosystem 
approach to aquaculture can leverage the potential of underutilized ponds for small-scale fish production, providing in the process a secondary option for household-level food production and income generation. However, the preliminary observations also suggested that despite its potential for the active and meaningful engagement of women in small-scale aquaculture, training and capacity-building would be needed to both effectively implement the ecopond model and maximize its possible outcomes (see Conceptual Framework for more information about the expected outcomes).

To test at a larger scale, the potential of the ecoponds model, WorldFish facilitated the development of (a) women groups in rural communities, (b) training to instill leadership skills to some women farmers (i.e. lead farmers, see more details in next paragraph), and (c) learning centers to facilitate this learning process in an iterative manner (rather than one-off) (WorldFish 2017). In particular, following an initial training, the participating women could visit the training centers multiple times as per their needs, having ready access to extension personnel to receive assistance on ecopond development and management.

Central to the ecoponds model was the initial training of some women farmers in each intervention community from WorldFish personnel to instill them with leadership skills. Through this early training, these selected women assumed the role of lead farmers, enabling them in turn to provide training to other women farmers in their communities with the help of extension staff. This training consisted of a series of sessions focusing on technical, value chain and women's empowerment aspects (see Box S1 in Supplementary Material for more details in this training). This training reached a total of 297 lead farmer women across the study area. The underlying rationale was that the women lead farmers would act as a constant reference point of ecoponds information within their communities (Box S1, Supplementary Material). By virtue of being local women also involved in fish production in their own ecoponds, it was expected that the women lead farmers could provide more confidence to the other local women targeted by WorldFish in each community to seek information, which might not have been the case if they had to refer to men lead farmers or extension personnel external to the community.

The wider Ecoponds training activities reached 3377 women in the Khulna and Barguna districts (see next section), transforming 3750 underutilized homestead ponds to ecoponds adopting the management practices outlined above.

\section{Conceptualizing women's role and empowerment in the Ecoponds intervention}

Women have been the focus of the Ecoponds intervention, as they are the main caretakers of their households (and thus responsible for nutrition). However, as mentioned in the Introduction, women are also largely excluded from aquaculture activities in larger ponds that have accounted for most aquaculture growth in Bangladesh. This is mainly because women lack access and control over inputs (e.g. capital, land) and therefore find it difficult to invest in more intensified production methods that could otherwise enhance fish productivity and production, as well as other aligned benefits. With men mostly controlling investment decisions in ponds, women in rural Bangladesh are usually unable to apply the knowledge obtained through aquaculture training to larger ponds (Choudhury et al. 2017; Farnworth et al. 2016; Morgan et al. 2015).

However, due to their small size, the ponds used as 'ecoponds' are mostly underutilized or not utilized at all for fish production in most households (see "Ecoponds intervention"). As men in rural Bangladesh tend to normally consider these ponds of lower (or even no) importance for fish production, they are more willing to consider fish production in such ponds led by women household members. However, it was expected that using ecoponds productively over long periods of time would allow a larger supply of fish for household consumption, with women gradually building up confidence and obtaining the control of these ponds. Overall, it was expected that empowering women in this way to engage meaningfully in fish production would encourage a more proactive role over household decision-making (including food-purchasing decisions), having further possible ripple impacts for food security.

When delineating the above, this study recognizes the dual role of the ecopond model for women's empowerment, ${ }^{3}$ as both a mechanism to enhance sustainability and an outcome impact of the specific intervention (McDougall 2017; Lau 2020; Lawless et al. 2021).

First, women's empowerment is seen as an instrumental value acting as a mechanism/pathway to achieve outcomes that improve household income and enhance food security. Second, women's empowerment is seen as one of the impacts of the ecoponds model, along with impacts, such as improved yields, income generation and food security. In this sense, women's empowerment is seen as an intrinsic value seeking gender equality as a major sustainability benefit on its own right. To assess women's empowerment as an impact/outcome of the ecoponds intervention, the study adapts IFPRI's Women's Empowerment in Agriculture Index (WEAI) tool in the household survey (Stage 2) and the Ladder of Power and Freedom tool developed by GENNOVATE

\footnotetext{
${ }^{3}$ We adopt Naila Kabeer's definition of empowerment, which is "the expansion of people's ability to make strategic life choices in a context where this ability was previously denied to them" (Kabeer, 1999: 437). Strategic life choices are multidimensional and influenced by structures and norms, which this project did not address.
} 
in the Focus Group Discussions (FGDs) (Stage 3) (see "Data Collection" and "Data Analysis for more information).

\section{Conceptual framework}

This study adopts a sustainability science lens to elicit the impacts (and related pathways) of the ecoponds model, adopting many of the paradigm's central elements, such as the strong linkage between social and ecological systems, a user-oriented perspective, and an interdisciplinary approach, that utilizes different sources of knowledge and viewpoints (Komiyama and Takeuchi 2006; Lang et al. 2012; Kates 2011).

Figure S1 systematizes the expected impacts and impact pathways from the ecoponds model. In particular, the ecopond model hypothesizes two pathways where ecopond development and women's access and control over ecoponds lead to improved food security. First, the adoption of ecosystem approaches to aquaculture can boost fish species diversity and pond productivity. Combined with women's capacity-building schemes to manage these ponds, it was expected that it would allow these sources to become a stable fish source, thus increasing household food availability, stability, and reducing fish purchases (and associated expenses). Second, by selling excess fish output from ecoponds (if any) could provide income, which combined with women's control over this income, it would allow the purchase of other types of food, increasing thus dietary diversity.

Figure S2 in the supplementary material illustrates the three-stage process we followed to assess ecopond impacts. In summary, Stage 1 entails a rapid baseline household survey to design the impact assessment protocol. Stage 2 entails a comprehensive household survey to assess quantitatively the impacts across the pathways described above. Stage 3 was designed and undertaken after the analysis of the household survey results and entails a series of focus group discussions (FGDs) with selected respondents to identify why some of the expected impacts and pathways did not manifest as expected.

\section{Study sites and groups}

Two intervention and two control areas were selected to assess the impacts of the ecoponds model. In terms of groups, we survey households adopting the ecoponds model (i.e. intervention group) and households not adopting the ecoponds model (i.e. control group). However, as many households in rural Bangladesh engage in other aquaculture activities (see Introduction), larger aquaculture ponds are quite prevalent. For this reason, we study four distinct groups (Figure S3, Supplementary Material): (a) households that only have underutilized ponds and received the ecoponds training (ecoponds);

(b) households that have underutilized ponds, as well as other pond and ghers, and received the ecoponds training (ecoponds + );

(c) households that only have underutilized ponds but did not received the ecoponds training (control);

(d) households that have underutilized ponds, as well as other pond and ghers, but did not receive the ecoponds training (control+).

Considering the relative ease of developing ecoponds, there is a high likelihood that households not receiving the ecoponds training, could become aware of and adopt some (or all) of the management practices through word of mouth or by observing neighbors, friends, and family. Such spillover effects are quite common in aquaculture and agricultural interventions, where knowledge dissemination is a major component (Dompreh et al. 2020; Miyata and Manatunge 2004; Lee et al. 2019). To decrease the likelihood of spillover effects, we selected control groups in areas that did not receive the intervention, but were at some distance, located in separate polders, and shared largely similar characteristics with the intervention areas (Table S1, Supplementary Material). In particular, intervention groups (i.e. ecoponds, ecoponds + ) were collected from Polder 29 and Polder 43/1A, while control and control + groups from Polder 30 and Polder 43/2F (Figure S4, Supplementary Material).

\section{Data collection}

During Phase 1, we conducted a rapid baseline assessment (October 2018) in 300 randomly selected households that received the ecoponds training. Even though the results of this baseline survey are not reported in this paper, they helped us identify the possible impact pathways and relevant variables. Moreover, this baseline provided insights to design the final sampling protocol described below.

During Phase 2, we conducted a detailed household survey to assess the sustainability impacts of the ecoponds model. In total, 1328 households were randomly selected for the household survey, of which 666 households were located in Khulna district (Site 1) and 662 in Barguna district (Site 2) (Table S1, Supplementary Material). All groups were sampled randomly from lists that were developed prior to fieldwork, containing basic household information, such as the type and number of ponds. We focused relatively more on households that had only small underutilized ponds (i.e. ecopond and control groups) rather than households that had also other ponds (i.e. ecopond + and control + ), to reduce the effect that larger and more intensively utilized ponds might have on the study indicators (Table 1). The survey respondents 
Table 1 Sample size and distribution by district and religion of respondent

\begin{tabular}{lllll}
\hline District & Group & $N$ & Hindu & Muslim \\
\hline Site 1 & & & & \\
Khulna & Ecopond & 229 & $59 \%$ & $41 \%$ \\
Khulna & Control & 208 & $55 \%$ & $45 \%$ \\
Khulna & Ecopond + & 113 & $63 \%$ & $37 \%$ \\
Khulna & Control+ & 116 & $56 \%$ & $44 \%$ \\
Site 2 & & & & \\
Barguna & Ecopond & 220 & $4 \%$ & $96 \%$ \\
Patuakhali & Control & 218 & $7 \%$ & $93 \%$ \\
Barguna & Ecopond + & 119 & $5 \%$ & $95 \%$ \\
Patuakhali & Control+ & 105 & $4 \%$ & $96 \%$ \\
\hline
\end{tabular}

were the women who received the ecopond training (i.e. ecopond and ecopond + groups) and women from similar control households (i.e. control and control + groups). The questionnaire contained six modules including (a) general household characteristics; (b) fish production; (c) income and expenses; (d) intra-household decision-making; (e) food consumption patterns, and (f) women's empowerment (adapted from the WEAI). More information about the main study variables is included in the next section.

During Phase 3, we conducted focus group discussions (FGDs) to understand the drivers behind food-purchasing priorities. The FGDs were designed following the completion of the analysis of the main survey (Phase 2) and sought to identify why the observed increase of income from ecoponds does not seem to translate into higher dietary diversity as expected (Figure S1, Supplementary Material). The Ladder of Power and Freedom Tool was employed to understand what changes in important life decisions (including food choices) have occurred in households engaged in ecoponds (Petesch and Bullock 2018).

A total of eight FGDs were conducted divided across gender and religion, as these two variables were identified during Phase 1-2 as potential factors influencing food-purchasing decisions (Table S2, Supplementary Material). Each FGD contained 6-7 participants, and when possible both the women who received the ecopond training and their husband were invited to participate (each within their respective FGD group). The participating households were purposely selected based on the survey's results and the key impact pathways identified (Figure S1, Supplementary Material). Specifically FGD participants were randomly selected from the survey participants that exhibited all of the following criteria: (a) had attended ecopond training (i.e. belonged to ecopond or ecopond + groups), (b) exhibited low or borderline dietary diversity in terms of the Food Consumption Score (FCS <42) (see below), and (c) experienced income generation from the ecoponds.

\section{Data analysis}

\section{Main impact variables}

Following Figure S1 (Supplementary Material), the main impacts captured in this study include (a) fish production and diversity, (b) household income and expenses, (c) food serving priority, (d) food security, and (e) women's empowerment. Below we outline the main variables and analysis for each of these impact categories.

For fish production and fish species diversity, we estimate total fish production and production per species from all available sources in each household (i.e. ponds, ghers, open waters, underutilized ponds/ecoponds). To express different types of productivity, we estimate these variables for the entire household and per unit area.

For income and expenses, we aggregate all major and minor income streams and expenses within the household, captured in Bangladeshi Taka (BDT) and subsequently converted in United States Dollars (USD) (1 USD = 84.5 BDT). Income and expenses are expressed in absolute and Adult Equivalent (AE) values. Since there is no standardized such scale found in Bangladesh official reports, we use the OECD-modified equivalent scale where a value of 1 is assigned to the household head, 0.5 is assigned for each subsequent adult, and 0.3 to each child.

For food serving priority, we requested respondents to use a 5-level Likert scale, to rank the serving, order of all household members, including those that were not present at the moment of the survey (e.g. pregnant women, lactating women). This indicator is used as a proxy for intra-household dynamics.

For food security, we use three different variables that provide complementary views, namely (a) the Food Consumption Score (WFP 2008); (b) fish consumption; (c) diversity of consumed fish. The FCS is a standardized measure of dietary diversity, measuring the consumption of nine standardized food groups over a recall period of seven days (Table S3, Supplementary Material). The overall household fish consumption assesses the availability of fish within the household. The diversity of consumed fish is a proxy for household access to a wider range of micronutrients, due to more diversified fish consumption.

For women's empowerment, we use a modified version of the Women's Empowerment in Agriculture Index (WEAI) (Alkire et al. 2013). We adjusted the WEAI to properly reflect fish production as the main livelihood source and overcome its over-focus on agricultural practices. Nine indicators (out of the original ten) across five dimensions were captured, namely (a) production, (b) resources, (c) income, (d) leadership, and (e) time. One indicator was not captured due to the fact that not all households have access to certain types of productive assets (i.e. farmlands). We calculate the 
overall WEAI for each group following the method proposed by Alkire et al. (2013).

We report variable levels for each of the four study groups in each study site. In each site, we compare variable levels only for comparable groups, i.e. "ecoponds vs. control" and "ecoponds + vs. control +". Treatment outcomes are elicited through (a) the comparison of average variable scores using inferential statistic techniques (i.e. $t$ test for parametric data, Mann-Whitney test for non-parametric data) and (b) Propensity Score Matching (PSM) to reduce possible treatment assignment bias (see next section).

\section{Propensity score matching}

The PSM approach has been increasingly used to correct for biases in the adoption of agricultural interventions and to estimate causal treatment effect (Ahmed et al. 2019; Caliendo and Kopeinig, 2005; Dompreh et al. 2020). In this study, we use the PSM to assess how the adoption of the good management practices and training outlined above affect household fish production (in terms of fish species diversity and total fish harvest), income, and food security (captured through the FCS and the diversity of consumed fish species).

For the PSM analysis, we use SPSS version 23 with the PSMatching 3.04 extension. The confounders used in the model include the age of the household member in charge of managing the pond, her total years of schooling, main religion of the household, working status (dummy variable: $0=$ engaged in a formal/informal paid job, $1=$ otherwise), and number of months within a year the household reported food insecurity as a proxy of unobservable socio-economic variables (Table S4, Supplementary Material).

Multiple matching techniques and setup combination (i.e. use of calipers, discard of units outside the common support group, sub-classification, and match ratio) are employed (Table S5, Supplementary Material). In all analyses, we use the nearest neighbor matching with a combination of calipers at 0.1 and removing units outside the common support group, as it produces the lowest relative multivariate imbalance and thus the best matching (Iacus et al. 2009).

\section{Qualitative analysis of FGDs}

The FGDs use a combination of open-ended and Likert scale questions to understand the priority that households ascribe to a diverse diet, the types of expenditures, and intra-household dynamics. The generic Likert scale questions are used to elicit the current food security perceptions within the household and improvement due to the ecopond training and overall intervention. For perceptions of empowerment, we use an adaptation of the ladder of Power and Freedom to elicit each individual's power and freedom to make important life decisions (Petesch and Bullock 2018). We calculate the consensus levels for these questions, with a consensus level of " 1 " representing complete consensus and " 0 " complete disagreement in the group.

The open-ended questions focus on the diet and expenditure priorities within the participants' households. Issues that were most discussed by participants are classified as having "high" priority, issues that were somewhat discussed are classified as "medium" priority, and issues that were not mentioned (or were quickly mentioned by one participant) were classified as "low" priority.

\section{Results}

\section{Sample characteristics}

All groups across both sites share similar general characteristics (Table 2). Household sizes are slightly higher in the study site 2, which is characterized by a Muslim majority. In terms of diet diversity, on average, all groups have an acceptable FCS, with scores higher that the 35 cut-off point. The relevance and importance of ecoponds is evident for all groups, in that they represent the highest or second-highest source of fish for the households.

\section{Fish production and diversity}

In both study sites, the households receiving the ecopond training and implementing the recommended production practices produce a higher diversity of fish species compared to their respective control groups, with significant differences in about half of these comparisons (Table 3). In Study Site 1, treatment households without other ponds produce a significantly higher diversity of fish species $(M=4.65)$ compared to their control group $(M=4.29)$ (i.e. ecopond vs. control). Similarly, in Study Site 2, treatment households without other ponds produce a significantly higher diversity of fish species $(\mathrm{M}=4.51)$ compared to their control group $(\mathrm{M}=3.83)$. Households receiving treatment and have other ponds (ecoponds + ) have generally higher fish diversity than their controls (control+), though the differences are not statistically significant. The results are rather similar between the treatment/control sampling method and the PSM method, though in some cases, they have lower significance or are not statistically significant (Table 3 ).

While for some comparisons control groups produce larger total amounts of fish compared to treatment households (Table S6, Supplementary Material), when adjusted per pond size, households that received ecopond training have consistently a higher productivity per unit area across sites, groups, and statistical tests (Table 4). For example, in Study Site 1, control groups had a higher total fish 
Table 2 Household characteristics by study site and group

\begin{tabular}{|c|c|c|c|c|c|c|c|c|}
\hline \multirow[t]{2}{*}{ Indicator } & \multicolumn{4}{|c|}{ Study site 1} & \multicolumn{4}{|c|}{ Study site 2} \\
\hline & Ecopond & Control & Ecopond + & Control+ & Ecopond & Control & Ecopond + & Control + \\
\hline \multicolumn{9}{|l|}{ General characteristics } \\
\hline Sample size (number) & 229 & 208 & 113 & 116 & 220 & 218 & 119 & 105 \\
\hline Age of respondent (years) & 40 & 39 & 39 & 40 & 41 & 40 & 42 & 39 \\
\hline Education of respondent (years) & 5.3 & 5.3 & 6.3 & 5.9 & 4.7 & 4.8 & 4.5 & 5.7 \\
\hline Household Size (persons) & 4.3 & 4.2 & 4.5 & 4.4 & 4.8 & 4.6 & 4.8 & 4.8 \\
\hline Food consumption score (units) & 65.8 & 63.6 & 65.9 & 69.8 & 63.6 & 61.6 & 64.9 & 67.7 \\
\hline \multicolumn{9}{|l|}{ Fish production by source (kg/year) } \\
\hline Pond & 0.0 & 0.0 & 35.9 & 67.9 & 0.0 & 0.0 & 113.0 & 99.6 \\
\hline Gher & 0.0 & 0.0 & 124.1 & 188.4 & 0.0 & 0.0 & 17.1 & 25.1 \\
\hline Open water & 32.8 & 69.4 & 19.8 & 20.4 & 21.9 & 57.9 & 20.9 & 27.4 \\
\hline Buy fish & 44.2 & 28.8 & 48.3 & 23.9 & 50.2 & 60.9 & 44.9 & 44.5 \\
\hline Received as gift & 5.6 & 1.6 & 2.3 & 1.6 & 0.6 & 0.3 & 0.5 & 0.4 \\
\hline Ecopond//underutilized pond & 88.9 & 74.6 & 79.4 & 62.1 & 135.1 & 68.1 & 97.0 & 61.6 \\
\hline
\end{tabular}

Table 3 Diversity of produced fish species across sampling groups, study sites and statistical tests

\begin{tabular}{|c|c|c|c|c|c|c|}
\hline & \multicolumn{3}{|c|}{ Sampling groups } & \multicolumn{3}{|c|}{ Propensity score matching } \\
\hline & Treated & Control & Sig & After treatment & $\begin{array}{l}\text { Before } \\
\text { treatment }\end{array}$ & Sig \\
\hline \multicolumn{7}{|c|}{ Fish species diversity (Count) } \\
\hline \multicolumn{7}{|l|}{ Study site 1} \\
\hline Ecopond vs control & 4.65 & 4.29 & $0.010^{* *}$ & 4.62 & 4.33 & 0.076 \\
\hline $\begin{array}{l}\text { Ecopond + vs control + } \\
\text { Study site } 2\end{array}$ & 5.50 & 5.22 & 0.311 & 5.52 & 5.26 & 0.165 \\
\hline Ecopond vs control & 4.51 & 3.83 & $0.000 * * *$ & 4.43 & 3.84 & $0.001 * * *$ \\
\hline Ecopond + vs control + & 5.29 & 4.88 & $0.033^{*}$ & 5.45 & 4.82 & $0.010 * *$ \\
\hline
\end{tabular}

Note: $* * * p<0.001 ; * * p<0.01, * p<0.05$ production (control $\mathrm{M}=144.0$; control $+\mathrm{M}=338.8$, respectively) compared to the Ecopond treatment groups (ecoponds $M=121.6$; ecoponds $+M=259.3$, respectively) (Table $S 6$, Supplementary Material). However, when compared in terms of fish production per unit area, ecopond treatment groups have a higher fish production (without considering fish harvested from open waters) compared to their respective control groups (Table 4). In Study Site 2, Ecopond treatment groups have a higher total fish production (ecopond $\mathrm{M}=157.1$, ecopond $+\mathrm{M}=247.9$, respectively) compared to their control groups (control $\mathrm{M}=125.9$, control $+M=213.7$ ) (Table S6, Supplementary Material). However, when comparing their production per unit area, we find a statistically significant difference between total fish production per unit area in Ecopond treatments (ecopond $\mathrm{M}=16.89$, ecopond $+\mathrm{M}=27.89$ ) compared to their respective control groups (control $M=11.86$, control $+M=20.19$, respectively) (Table 4).

It is worth noting that despite variations in total fish production across the different types of ponds/areas used for fish production between groups (Table S6, Supplementary Material), ecoponds exhibit the highest fish productivity per unit area compared to ghers or any other type of ponds (Table S7, S8, Supplementary Material). All the patterns outlined above have rather similar means between groups measured through $\mathrm{t}$ test inferential statistics and the PSM analysis (Table 4 and Table S6, S7, S8 Supplementary Material).

\section{Income and expenditure}

Across all study sites, ecoponds play a major role for income generation, accounting for up to $70 \%$ of the total income from fish sales for households not having other ponds (Table 5). In Study Site 1, while ecopond groups produce significantly more fish from ecoponds $(\mathrm{M}=89 \mathrm{~kg}$ compared to their control group from similar underutilized ponds $(\mathrm{M}=75 \mathrm{~kg})$ (Table S7, Supplementary Material), they have a lower income from fish sales from ecoponds/ underutilized ponds per adult equivalent $(\mathrm{M}=51 \mathrm{USD} / \mathrm{AE} /$ year) compared to their control group ( $\mathrm{M}=60 \mathrm{USD} / \mathrm{AE} /$ 
Table 4 Fish productivity across sampling groups, study sites and statistical tests (in $\mathrm{kg} /$ decimal/year)

\begin{tabular}{|c|c|c|c|c|c|c|}
\hline \multirow[b]{2}{*}{ Sampling Group } & \multicolumn{3}{|c|}{ Sampling groups } & \multicolumn{3}{|c|}{ Propensity score matching } \\
\hline & Treated & Control & Sig. & After treatment & Before treatment & Sig. \\
\hline \multicolumn{7}{|l|}{ Study site 1} \\
\hline \multicolumn{7}{|l|}{ Ecopond vs control } \\
\hline Anabas/Perch & 0.60 & 0.31 & $0.022^{*}$ & 0.63 & 0.27 & $0.015^{*}$ \\
\hline Catfish & 1.54 & 0.96 & 0.104 & 1.48 & 0.97 & 0.170 \\
\hline Carp & 6.82 & 6.39 & 0.561 & 6.53 & 6.43 & 0.900 \\
\hline Small indigenous fish & 1.19 & 0.71 & $0.000 * * *$ & 1.26 & 0.72 & $0.000 * * *$ \\
\hline Snakehead & 1.02 & 0.71 & $0.021^{*}$ & 1.04 & 0.70 & $0.028 *$ \\
\hline Tilapia & 4.35 & 3.24 & $0.025^{*}$ & 4.44 & 3.19 & $0.029 *$ \\
\hline Other & 0.66 & 0.53 & 0.539 & 0.68 & 0.57 & 0.638 \\
\hline Total & 16.18 & 12.84 & $0.005 * *$ & 16.06 & 12.85 & $0.000 * * *$ \\
\hline \multicolumn{7}{|l|}{ Ecopond + vs Control+ } \\
\hline Anabas/Perch & 0.88 & 0.41 & $0.000 * * *$ & 0.89 & 0.41 & $0.001 * *$ \\
\hline Catfish & 2.04 & 0.84 & $0.016^{*}$ & 2.21 & 0.85 & $0.020^{*}$ \\
\hline Carp & 10.33 & 11.23 & 0.580 & 10.45 & 11.73 & 0.458 \\
\hline Small indigenous fish & 2.44 & 1.06 & $0.001 * *$ & 1.96 & 1.12 & $0.015^{*}$ \\
\hline Snakehead & 2.00 & 1.16 & $0.007 * *$ & 1.80 & 1.18 & $0.031 *$ \\
\hline Tilapia & 6.01 & 4.41 & 0.127 & 6.11 & 4.39 & 0.143 \\
\hline Other & 1.31 & 1.63 & 0.421 & 1.40 & 1.72 & 0.497 \\
\hline Total & 25.01 & 20.74 & 0.116 & 24.82 & 21.42 & $0.000 * * *$ \\
\hline \multicolumn{7}{|l|}{ Study site 2} \\
\hline \multicolumn{7}{|l|}{ Ecopond vs control } \\
\hline Anabas/Perch & 0.37 & 0.12 & $0.000 * * *$ & 0.37 & 0.12 & $0.001 * * *$ \\
\hline Catfish & 2.38 & 2.28 & 0.806 & 2.37 & 2.37 & 0.999 \\
\hline Carp & 5.93 & 4.50 & $0.005 * *$ & 5.88 & 4.74 & $0.043^{*}$ \\
\hline Small indigenous fish & 0.91 & 0.59 & $0.010^{*}$ & 0.93 & 0.54 & $0.004 * *$ \\
\hline Snakehead & 0.74 & 0.35 & $0.000 * * *$ & 0.72 & 0.36 & $0.002 * *$ \\
\hline Tilapia & 4.27 & 2.78 & $0.015^{*}$ & 4.46 & 2.99 & $0.028 *$ \\
\hline Other & 2.29 & 1.23 & 0.436 & 2.52 & 0.95 & 0.307 \\
\hline Total & 16.89 & 11.86 & $0.022^{*}$ & 17.24 & 12.05 & $0.000 * * *$ \\
\hline \multicolumn{7}{|l|}{ Ecopond + vs control+ } \\
\hline Anabas/Perch & 0.67 & 0.54 & 0.358 & 0.77 & 0.49 & 0.099 \\
\hline Catfish & 4.87 & 3.79 & 0.391 & 5.12 & 3.72 & 0.397 \\
\hline Carp & 9.47 & 8.24 & 0.414 & 9.55 & 7.46 & 0.203 \\
\hline Small indigenous fish & 2.13 & 1.03 & $0.000 * * *$ & 1.89 & 0.97 & $0.000 * * *$ \\
\hline Snakehead & 1.14 & 0.91 & 0.271 & 1.21 & 0.90 & 0.175 \\
\hline Tilapia & 6.62 & 4.38 & $0.002 * *$ & 6.68 & 4.19 & $0.01 * *$ \\
\hline Other & 2.99 & 1.30 & $0.015^{*}$ & 3.17 & 1.52 & $0.050 *$ \\
\hline Total & 27.89 & 20.19 & $0.002 * *$ & 28.39 & 19.25 & \\
\hline
\end{tabular}

Note: Small indigenous fish include mola, darkina, small chingri, punti, and other species rich in micronutrients. The decimal is a local unit of area equivalent $1 \mathrm{dec}=0.004$ ha; Fish harvest per unit area does not include fish species harvested from open waters; $* * * p<0.001 ; * * p<0.01, * p<0.05$ year) (Table 5). In Study Site 2, we found that in all cases, ecopond treatment groups have a higher income per adult equivalent from fish sales from ecoponds (ecoponds: $\mathrm{M}=86$ and ecoponds $+: \mathrm{M}=69 \mathrm{USD} / \mathrm{AE} /$ year, respectively) compared to the sales of their control groups from underutilized ponds (control: $\mathrm{M}=50$ and control $+: \mathrm{M}=52 \mathrm{USD} / \mathrm{AE} /$ year, respectively).
In terms of household expenditures, across all comparisons in both study sites, the households that received the treatment spend less money for purchasing fish compared to their respective control groups (Table S9, Supplementary Material), but the differences are mostly not statistically significant. Although across all groups, the highest household expenditure is for purchasing food items other than fish, the 
Table 5 Household income across sampling groups, study sites and statistical tests (in USD/AE/year)

\begin{tabular}{|c|c|c|c|c|c|c|}
\hline & \multicolumn{3}{|c|}{ Sampling groups } & \multicolumn{3}{|c|}{ Propensity score matching } \\
\hline & Treated & Control & Sig & After treatment & Before treatment & Sig \\
\hline \multicolumn{7}{|l|}{ Study site 1} \\
\hline \multicolumn{7}{|l|}{ Ecopond vs control } \\
\hline Agriculture & 221 & 161 & 0.057 & 194 & 170 & 0.235 \\
\hline Ecopond/underutilized pond fish sales & 51 & 60 & 0.170 & 49 & 62 & 0.084 \\
\hline Other fish sales & 29 & 35 & 0.405 & 26 & 37 & 0.160 \\
\hline Part/Full time employment & 374 & 416 & 0.477 & 372 & 412 & 0.551 \\
\hline Livestock sales & 68 & 83 & 0.151 & 71 & 88 & 0.131 \\
\hline Other income activity & 76 & 35 & 0.078 & 82 & 33 & 0.072 \\
\hline Total Income & 818 & 789 & 0.683 & 794 & 801 & 0.926 \\
\hline \multicolumn{7}{|l|}{ Ecopond + vs control +} \\
\hline Agriculture & 200 & 388 & $0.001 * *$ & 206 & 421 & $0.002 * *$ \\
\hline Ecopond//underutilized pond fish sales & 41 & 37 & 0.559 & 42 & 37 & 0.535 \\
\hline Other fish sales & 145 & 240 & $0.004 * *$ & 139 & 265 & $0.001 * *$ \\
\hline Part/Full time employment & 392 & 392 & 0.996 & 411 & 330 & 0.424 \\
\hline Livestock sales & 72 & 86 & 0.336 & 72 & 86 & 0.410 \\
\hline Other income activity & 56 & 56 & 0.998 & 62 & 47 & 0.597 \\
\hline Total income & 907 & 1,200 & $0.025^{*}$ & 932 & 1,185 & 0.061 \\
\hline \multicolumn{7}{|l|}{ Study site 2} \\
\hline \multicolumn{7}{|l|}{ Ecopond vs control } \\
\hline Agriculture & 191 & 171 & 0.486 & 200 & 178 & 0.485 \\
\hline Ecopond//underutilized pond fish sales & 86 & 50 & 0.101 & 87 & 51 & 0.148 \\
\hline Other fish sales & 37 & 25 & 0.463 & 39 & 24 & 0.397 \\
\hline Part/Full time employment & 508 & 597 & 0.082 & 527 & 600 & 0.172 \\
\hline Livestock sales & 102 & 97 & 0.750 & 110 & 104 & 0.738 \\
\hline Other income activity & 96 & 180 & $0.011 *$ & 85 & 175 & $0.013 *$ \\
\hline Total Income & 1,020 & 1,120 & 0.143 & 1,048 & 1,132 & 0.273 \\
\hline \multicolumn{7}{|l|}{ Ecopond + vs control +} \\
\hline Agriculture & 218 & 226 & 0.818 & 225 & 214 & 0.762 \\
\hline Ecopond//underutilized pond fish sales & 69 & 52 & $0.027 *$ & 68 & 50 & $0.040^{*}$ \\
\hline Other fish sales & 108 & 113 & 0.792 & 113 & 102 & 0.650 \\
\hline Part/Full time employment & 618 & 458 & 0.072 & 644 & 475 & 0.165 \\
\hline Livestock sales & 117 & 129 & 0.577 & 117 & 120 & 0.922 \\
\hline Other income activity & 61 & 141 & 0.063 & 61 & 163 & 0.055 \\
\hline Total income & 1,191 & 1,119 & 0.494 & 1,229 & 1,124 & 0.339 \\
\hline
\end{tabular}

Note: $* * * p<0.001 ; * * p<0.01, * p<0.05$

groups with ecopond treatment tend to spend comparatively less money to purchase other types of food (Table S9, Supplementary Material).

\section{Dietary diversity and eating order}

There is no significant difference in terms of dietary diversity (i.e. FCS) between treatment and control groups in any of the study sites (Table 6). For all study groups, the obtained FCS scores are above the threshold of 39 points, indicating a rather acceptable food security in terms of dietary diversity. Overall, most treatment groups have a slightly higher FCS compared to their control groups, while the Ecopond + groups have a slightly lower FCS compared to their control groups. However, in all cases, treatment groups consume a higher diversity of fish species compared to their respective control groups, with the differences having no or low statistical significance (Table 6).

However, all Ecopond treatment groups consume higher quantities of fish per adult equivalent compared to their respective control groups, but with not all differences being statistically significant (Table S10, Supplementary Material). In Study Site 1, Ecopond group consumes significantly more fish per adult equivalent $(\mathrm{M}=55.26 \mathrm{~kg} / \mathrm{AE} / \mathrm{year})$ 
Table 6 Dietary diversity and diversity of consumed fish species across sampling groups, study sites and statistical tests
Table 7 Modified WEAI and household fraction with women's empowerment adequacy across groups and study sites

\begin{tabular}{|c|c|c|c|c|c|c|}
\hline & \multicolumn{3}{|c|}{ Sampling groups } & \multicolumn{3}{|c|}{ Propensity score matching } \\
\hline & Treated & Control & Sig & After treatment & $\begin{array}{l}\text { Before } \\
\text { treatment }\end{array}$ & Sig \\
\hline \multicolumn{7}{|l|}{ Dietary diversity (FCS) } \\
\hline \multicolumn{7}{|l|}{ Study Site 1} \\
\hline Ecopond vs Control & 65.8 & 63.6 & 0.227 & 65.8 & 64.8 & 0.616 \\
\hline \multicolumn{7}{|l|}{ Study Site 2} \\
\hline Ecopond vs Control & 63.6 & 61.6 & 0.271 & 64.1 & 62.3 & 0.346 \\
\hline Ecopond + vs Control + & 64.9 & 67.7 & 0.218 & 65.3 & 66.8 & 0.564 \\
\hline \multicolumn{7}{|c|}{ Fish SpeciesDiversity (Count) } \\
\hline \multicolumn{7}{|l|}{ Study Site 1} \\
\hline Ecopond vs Control & 5.46 & 5.13 & $0.017 *$ & 5.46 & 5.14 & $0.012^{*}$ \\
\hline $\begin{array}{l}\text { Ecopond + vs Control+ } \\
\text { Study site } 2\end{array}$ & \multicolumn{5}{|c|}{ Study site 2} & $0.004 * *$ \\
\hline Ecopond vs control & 5.41 & 5.14 & $0.036^{*}$ & 5.34 & 5.17 & 0.189 \\
\hline Ecopond + vs control + & 5.74 & 5.71 & 0.722 & 5.85 & 5.73 & 0.497 \\
\hline \multicolumn{7}{|c|}{ Note: $* * * p<0.001 ; * * p<0.01, * p<0.05$} \\
\hline \multirow[t]{2}{*}{ Sampling group } & \multicolumn{3}{|l|}{ WEAI } & \multicolumn{3}{|c|}{ Empowerment adequacy } \\
\hline & $\begin{array}{l}\text { Treatment } \\
\text { (score) }\end{array}$ & & $\begin{array}{l}\text { rol groups } \\
\text { e) }\end{array}$ & $\begin{array}{l}\text { Treatment }(\% \\
\text { of } \mathrm{HH})\end{array}$ & $\begin{array}{l}\text { Control (\% of } \\
\mathrm{HH})\end{array}$ & Sig \\
\hline \multicolumn{7}{|l|}{ Study site 1} \\
\hline Ecopond vs control & $85 \%$ & 80 & & $77 \%$ & $67 \%$ & $0.020^{*}$ \\
\hline $\begin{array}{l}\text { Ecopond + vs control+ } \\
\text { Study site } 2\end{array}$ & $83 \%$ & 84 & & $74 \%$ & $75 \%$ & 0.908 \\
\hline Ecopond vs control & $84 \%$ & 81 & & $69 \%$ & $62 \%$ & 0.115 \\
\hline Ecopond + vs control + & $86 \%$ & 81 & & $74 \%$ & $59 \%$ & $0.018^{*}$ \\
\hline
\end{tabular}

Note: ${ }^{* * *} p<0.001 ; * * p<0.01, * p<0.05$ compared to their control group ( $\mathrm{M}=43.94 \mathrm{~kg} / \mathrm{AE} / \mathrm{year})$. Moreover, across all comparisons in both study sites, the consumed quantity of fish by species is often higher among Ecopond treatment groups, compared to their respective control groups.

There is no significant difference in the periods of selfreported food insecurity between study groups in any of the study sites (Table S11 Supplementary Material). While the proportion of household reporting monthly food insecurity peaks at $7 \%$ and $5 \%$, respectively, the actual period when this occurs differs between sites (Figure S5, S6, Supplementary Material). In Study Site 1, the self-reported period of food insecurity starts in the second quarter of the year (May-Aug) and peaks during the last quarter of the year (Sep-Oct) (Figure S5, Supplementary Material). However, food insecurity peaks during the second quarter of the year (May-Aug) in Study Site 2 (Figure S6, Supplementary Material).

Regarding intra-household dynamics, there is no evidence of significant change between groups in terms of eating order including vulnerable groups, such as pregnant and lactating women, in any of the study sites (Table S12, Supplementary Material). However, it is noteworthy to mention that results show men often have a higher serving priority compared to women for a given group.

\section{Women's empowerment}

As mentioned in the Methodology, we calculate the overall empowerment score for each group along the five dimensions of (a) production (input to and autonomy in production), (b) resources (access to and decisions on credit as well as ownership of resources), (c) income (control over use), (d) leadership (group membership and speaking in public), and (e) time (leisure and workload).

The results indicate the slightly higher overall women's empowerment among Ecopond treatment groups in terms of the absolute modified WEAI, compared to their control counterparts, for 3 out of the 4 group comparisons for both tests (Table 7). However, in most cases, the difference is not statistically significant between group comparisons 
Table 8 Focus group discussion outcomes for the Likert scale questions
Consumption of suffi- $\quad$ Freedom to make major Improvement of decicient and preferred food household decisions sion-making power following ecopond training

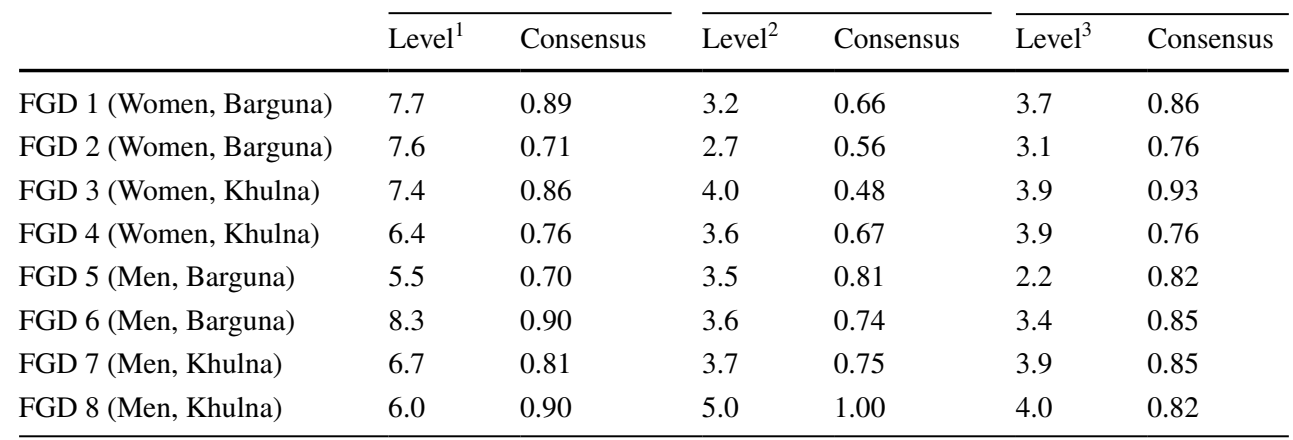

Note: ${ }^{1}$ Scale from 1 (not at all) to 10 (very much); ${ }^{2}$ Scale from $1=$ Almost no power or freedom to make decisions, $2=$ Only a small amount of power $\&$ freedom, $3=$ Power $\&$ freedom to make some major life decisions, $4=$ Power $\&$ freedom to make many major life decisions, $5=$ Power $\&$ freedom to make most or all major life decisions; ${ }^{3}$ Scale from $1=$ No improvement, $2=$ Improved to have small power on major life decisions, $3=$ Improved to have some power on major life decisions, $4=$ Improved to have major power on major life decisions, $5=$ Improved to have most power on major life decisions
(Table 7). It is interesting to point that there are no clear differences between scores for similar groups from Study Site 1 that contains an equal mix of Hindu and Muslim households, and Study Site 2 that contains predominantly Muslim households (Table 1).

When looking at the individual dimensions of women's empowerment, one of the most interesting findings is that the majority of women engaged in small-scale aquaculture in underutilized ponds controls the relevant income (see indicator I1, Table S13, Supplementary Material). Ecoponds households have a generally higher empowerment adequacy in this dimension, but the difference is not statistically significant in any of the comparisons with control households. However, when it comes to asset ownership (indicator R1), ecoponds households have significantly higher empowerment adequacy than control households in most comparisons.

Consistently the lowest empowerment adequacy is for the "access to and decisions over credit" (see indicator R3, Table S13, Supplementary Material). Again even though ecoponds households have higher empowerment adequacy for this dimension, the differences are not statistically significant with control groups. Finally, it is worth noting that empowerment adequacy for workload indicator is higher (but not significantly) for two of the comparisons with control groups, and the same for the other two (see indicator T1, Table S13, Supplementary Material).

\section{Focus group discussion analysis}

As outlined above, the FGDs consisted of purposefully selected households that had reported income gains from engagement in ecopond activities but had low or borderline dietary diversity in terms of the FCS. Through this extra layer of analysis, we sought to understand whether income from ecopond activities is invested to buy other food items, and if not, why.

First, the women FGD participants attested that they have the freedom to make some major life decisions, including allocation of household expenses for consumption decisions, and that participation in the ecopond intervention has improved to some extent this ability, with some high degree of consensus (Table 8). This suggests that in theory those women could invest their ecopond income to buy food to increase dietary diversity within the household.

However, even though there is an overall understanding of the value of a preferred and nutritious diet and its prioritization over absolute quantity, it seems that other priorities within the household take precedence (Fig. 1). In particular, participants across all FGDs articulated a lower priority towards spending any extra income for diet diversification. Instead, education and increased productivity are viewed as the main priorities (Fig. 1), or as one participant mentioned "spending the extra income on increasing productivity will give me more profit. Then I can use the profit for family welfare" (Participant 1, FGD3).

Follow-up questions regarding challenges to diversify household diet did not reveal major barriers regarding decisions over food expenditures. For example, one of the participants suggested that: "if there is any need for my family, I tell my husband and he never refuses me [...], the money earn by selling these [fish] remains in my hand" (Participant 2, FGD 2). 
Fig. 1 Focus group discussion outcomes for the open-ended questions
Fig. 2 Schematic representation of impact pathways and observed trends

\begin{tabular}{|c|c|c|c|c|c|c|c|c|}
\hline & FGD1 & FGD2 & FGD3 & FGD4 & FGD5 & FGD6 & FGD7 & FGD8 \\
\hline \multicolumn{9}{|l|}{ Diet priorities } \\
\hline Food quantity & $\square$ & $\square$ & $\triangle$ & $\square$ & $\square$ & $\triangle$ & $\nabla$ & $\nabla$ \\
\hline Eat prefered food & $\Delta$ & $\Delta$ & $\Delta$ & $\nabla$ & $\triangle$ & $\Delta$ & $\square$ & $\Delta$ \\
\hline Nutrition & $\Delta$ & $\square$ & $\nabla$ & $\Delta$ & $\Delta$ & $\nabla$ & $\Delta$ & $\Delta$ \\
\hline \multicolumn{9}{|l|}{ Expenditure priorities } \\
\hline Children education & $\triangle$ & $\square$ & $\triangle$ & $\Delta$ & $\Delta$ & $\square$ & $\triangle$ & $\triangle$ \\
\hline Increase productivity & $\triangle$ & $\triangle$ & $\nabla$ & $\Delta$ & $\Delta$ & $\triangle$ & $\triangle$ & $\triangle$ \\
\hline Heallthcare and wellfare & $\triangle$ & $\square$ & $\square$ & $\square$ & $\nabla$ & $\square$ & $\square$ & $\square$ \\
\hline Food diversity & $\nabla$ & $\nabla$ & $\square$ & 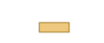 & $\nabla$ & $\nabla$ & $\nabla$ & $\nabla$ \\
\hline
\end{tabular}

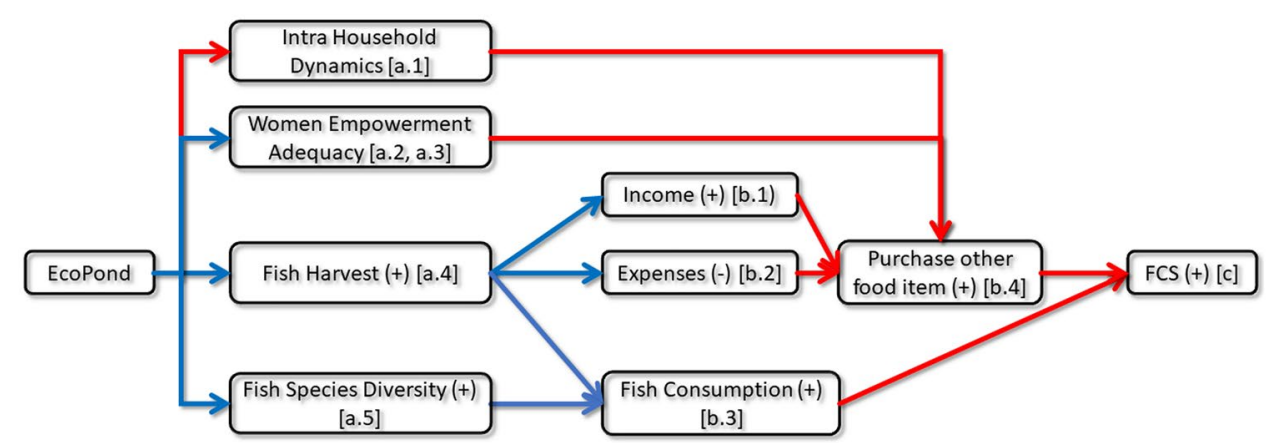

$\rightarrow$ Not supported by the outcomes

$\rightarrow$ Supported by the outcomes
Fig. 3 Summary of sustainability impacts by study site and group comparison

\begin{tabular}{|c|c|c|c|c|c|c|c|c|c|c|}
\hline \multirow{3}{*}{ Ecopond Treatment } & \multicolumn{4}{|c|}{ Study Site 1} & \multicolumn{4}{|c|}{ Study Site 2} & \multirow{2}{*}{\multicolumn{2}{|c|}{$\begin{array}{l}\text { Total } \\
\text { Ecopond }\end{array}$}} \\
\hline & \multicolumn{2}{|c|}{ Ecopond } & \multirow{2}{*}{\multicolumn{2}{|c|}{\begin{tabular}{|l} 
Ecopond+ \\
Result Sig.
\end{tabular}}} & \multicolumn{2}{|c|}{ Ecopond } & \multicolumn{2}{|c|}{ Ecopond+ } & & \\
\hline & Result & Sig. & & & Result & Sig. & Resul & Sig. & Higher (\%) & Sig. (\%) \\
\hline [a.1] Intra-household dynamics & $\sqrt{4}$ & - & $\sqrt{4}$ & - & $\sqrt{4}$ & - & $\sqrt{y}$ & - & 0 & - \\
\hline [a.2] WEAI & 雨 & - & $\sqrt{\omega}$ & - & 舟 & - & 印 & - & 0 & - \\
\hline [a.3] $\mathrm{HH}$ with women empowerment adequacy & 卌 & $\checkmark$ & $\Downarrow$ & $x$ & 雨 & $x$ & 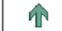 & $\nabla$ & 0 & (1) \\
\hline [a.4] Increase Ecopond harvest (per decimal) & त & $\checkmark$ & 瓜 & $\checkmark$ & 斥 & $\checkmark$ & 舟 & $\checkmark$ & 0 & 0 \\
\hline [a.5] Increase in fish varieties & 雨 & $\checkmark$ & 雨 & $x$ & 雨 & $\vartheta$ & 雨 & 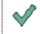 & 0 & 0 \\
\hline [b.1] Higher income from ecoponds & $\Downarrow$ & $x$ & 斥 & $x$ & 雨 & $\mathrm{x}$ & 舟 & $\checkmark$ & D & () \\
\hline [b.2] Decrease expendutire on fish (per AE) & 舟 & $x$ & 雨 & $x$ & 舟 & $x$ & 舟 & $\checkmark$ & 0 & () \\
\hline insumption (per AE) & 雨 & $\checkmark$ & 斥 & $x$ & 舟 & $x$ & 雨 & $x$ & 0 & C) \\
\hline [b.4] Purchase other food items (per AE) & $\sqrt{2}$ & $\nabla$ & $\sqrt{\Downarrow}$ & $\checkmark$ & $\sqrt{ }$ & $x$ & $\sqrt{4}$ & $x$ & 0 & () \\
\hline [c] Higher Food Consumption Score & T & $x$ & $\sqrt{y}$ & $x$ & 雨 & $x$ & $\sqrt{y}$ & $x$ & (1) & 0 \\
\hline \multicolumn{9}{|c|}{$\begin{array}{l}\mathbb{W}=\text { Outcome higher than its respective control group } \\
\Downarrow=\text { Outcome lower than its respective control group } \\
\text { = Outcome significantly higher/lower than its respective control group } \\
\text { = Outcome not significantly higher/lower than its respective control group }\end{array}$} & \multicolumn{2}{|c|}{$\begin{aligned} & =0 \%(0 \text { cases }) \\
& =25 \%(1 \text { cases }) \\
& =50 \%(2 \text { cases }) \\
& =75 \%(3 \text { cases }) \\
& =100 \%(4 \text { cases })\end{aligned}$} \\
\hline
\end{tabular}

\section{Impact pathways outcomes}

Figures 2, 3 summarize the main findings of this study across the studied sustainability impacts. Overall, the results suggest that the intensification of small-scale aquaculture systems through ecosystem approaches for habitat provision can offer positive yet inconsistent benefits. In summary, the main impacts of the Ecoponds intervention can be summarized as:

- $\quad$ significant productivity and livelihood gains;

- moderate women's empowerment gains;

- inconsistent food security outcomes. 
These findings point to the real potential of ecosystembased approaches to small-scale aquaculture. However, as outlined in the Discussion, in order to achieve these sustainability benefits, it is necessary to understand some of the underlying mechanisms, as well as tackle constraints, especially those related to education, and broader cultural and socioeconomic factors.

\section{Discussion}

\section{Significant productivity and livelihood gains}

Notably, ecoponds have higher fish diversity, fish productivity per unit area, and income generation potential compared to similar underutilized ponds (Tables 3,4 ). This is evident in most group comparisons and is in most cases statistically significant (Fig. 3). Furthermore, per unit area, ecoponds are more productive than other types of ponds or ghers in the study areas, while ecopond fish productivities are higher in households that do not have other ponds (Table S8, Supplementary Material). This shows that indeed ecoponds can offer substantial productivity and livelihood benefits, suggesting their large potential for rural development in Bangladesh, and possibly other developing contexts. However, it is not clear from our results why these higher productivity manifest. For example, it might be that households that have other larger ponds do not invest significant input to household ecoponds (Chowdhury 2009), that the women involved in ecopond activities are willing to invest more time and care on managing the ecopond habitats, or that they harvest fish more regularly due to the limited other fish supply alternatives. Such mechanisms need to be understood better to further ascertain the potential for upscaling such aquaculture practices in Bangladesh and other similar developing contexts.

\section{Moderate women's empowerment gains}

A very crucial element of the study is that the ecoponds were actively managed by women, many of whom were not previously involved directly in fish production in their own ponds. As mentioned in the Introduction, women are mostly engaged in aquaculture in post-harvest activities, such as marketing and processing, but their role is often under-recognized or 'hidden' in value chain analyses (Eltholth et al. 2015; Shirajee et al. 2010; Kruijssen et al. 2018; Choo and Williams 2014; Gopal et al. 2014). In this study, there are some signs that engagement in ecoponds training and production is associated with higher women's empowerment, which is relatively uncommon considering this "hidden" role of women in Bangladesh aquaculture (Ahmed et al. 2012) (see also Introduction). In particular, there are relatively higher absolute WEAI scores for some treatment groups, but these improvements are not statistically significant (Table 7, Table S13, Supplementary Material; Fig. 3). However, ecopond households have higher empowerment adequacy for individual indicators, such as control of income and productive assets, with the latter being statistically significant for most comparisons (Table S13, Supplementary Material). Furthermore, some of the women FGD participants also indicate that the participation in ecopond training improved their ability/capacity to make major households decisions, but admittedly due to the confining participant selection criteria this might not be generalizable for the entire sample (Table 8).

Collectively, the above suggest that ecoponds indeed contribute to some aspects of women's empowerment by increasing their power over these underutilized ponds to improve productivity (via capacity-building) and the power to act on the training knowledge, as indeed evidenced in other small-scale aquaculture and fisheries contexts (Manyungwa et al. 2019; Park 2017; Frangoudes et al. 2019). However, it did not address power within or power with, such as the gender power relations that inhibit women's empowerment at multiple scales, thus leaving structural inequalities at large. The above suggest ecoponds have some women's empowerment potential but achieving women's empowerment in rural Bangladesh is a multifaceted process and/or that the ecoponds intervention only covers some of the important components of women's empowerment (i.e. control over ecoponds and ecopond income). This does not necessarily translate to control over other important life choices that Naila Kabeer's definition points towards, as again pointed in multiple other studies in small-scale aquaculture and fisheries contexts (Kruijssen et al. 2018; Cole et al. 2020).

In any case, even these moderate women's empowerment outcomes can be source of optimism, considering the general lack of women access and control over productive resources in rural contexts of Bangladesh (Ahmed et al. 2012; Aregu et al. 2018; Choudhury et al. 2017; Farnworth et al. 2016; Halim and Ahmed 2006; Shelly and D'Costa 2001). To further improve these aspects, Gender Transformative Approaches (GTA) can be built into the extension model to address the underlying social barriers women face, possibly sparking critical discussions on intra-household dynamics and gender norms (Choudhury and Castellanos 2020; Kantor et al. 2015; Cole et al. 2020). While "gender accommodative" approaches acknowledge these barriers but propose to "work around them", GTAs seek to reduce them by creating awareness about the gender roles and norms that lead to them (Cole et al. 2020). Essentially, projects using GTAs design-specific strategies and actions to contribute to behavioral changes in both men and women (Hillenbrand 
et al. 2014). In the context of our case study, a GTA could be one that helps translate to important elements of women's empowerment beyond aquaculture such as improve access to credit, which is by far the dimension of empowerment with consistently the lowest empowerment adequacy among all groups (Table S13, Supplementary Material). Furthermore, other GTAs could help address gender power relations that form structural barriers to women's empowerment across multiple scales (Wong et al. 2019; Kantor et al. 2015; Aregu et al. 2019).

\section{Inconsistent food security outcomes}

Interestingly, despite the gains in productivity, income, and empowerment described above, ecoponds have a relatively inconsistent impact on food security. On the one hand, it is evident across most comparisons that ecoponds/ecoponds + households consume more and more diverse fish, with the differences being statistically significant for many comparisons (Table 6; Fig. 3). Even though, carp and tilapia output and consumption are the highest in absolute terms among the different aquaculture species, there are also significant differences in the production and consumption of small indigenous fish among some groups (Table S6 and S10, Supplementary Material). These species are rich in micronutrients (e.g. vitamin A, iron, zinc, calcium) and have thus been identified as a possible option for reducing malnutrition among poor households and vulnerable groups (e.g. pregnant women, small children, lactating mothers) (Karim et al. 2017; Bogard et al. 2015), suggesting possible nutritional benefits for ecopond groups. ${ }^{4}$

However, the overall impacts of ecoponds on diet diversity (Table 6) or intra-household eating dynamics (Table S12, Supplementary Material) are not conclusive. As outlined during the FGDs, this lack of strong impact on dietary diversity might be likely due to the low prioritization of diversified diets compared to other household expenditures rather than women' control of income sources (see "FGD analysis" and Table S13, Supplementary Material). Previous studies have found that health and dietary concerns in rural areas characterized by low access to resource do not necessarily translate into more diversified dietary choices regardless of the food cost, partly due to misconceptions about the importance of certain food groups (Farris et al. 2020) and prioritization of income expenditure on other competing household needs, such as healthcare and education (Hendriks and Lyne 2003). Such mechanisms need to

\footnotetext{
${ }^{4}$ It is worth mentioning that the production of such a diverse set of species can help maintain aquatic biodiversity in Bangladesh (ICSF, 2010), especially considering the widespread degradation of aquatic habitats and the overexploitation of fish stocks from rivers, canals, and other wetlands in the country.
}

be understood better to understand better the food security potential of ecoponds in Bangladesh, and possibly improve the training necessary training packages.

\section{Implications and recommendations}

The results of this study clearly show that the intensification of small-scale aquaculture systems through ecosystem approaches has multiple sustainability benefits. In this sense, such interventions can help achieve localized progress across multiple Sustainable Development Goals (SDGs), such as SDG1 (No Poverty), SDG2 (Zero Hunger), SDG5 (Gender Equality) and SDG14 (Life Below Water), among others.

However, our results also show that the impacts do not manifest always manifest equally across all sustainability dimensions, often due to underlying constraints, such as lack of education or prevailing cultural and socioeconomic conditions. This strongly implies that to achieve the full potential of aquaculture (and more broadly development) interventions, the design and dissemination of new innovations must not only account for the expected sustainability outcomes (e.g. improved food security, poverty alleviation, gender empowerment), but also for the capacities and cultural and socioeconomic barriers that the target groups must overcome.

Towards that end, conducting ex-ante evaluations (e.g. defining locally appropriate theories of change, identifying impact mechanisms) and understanding the cultural and socioeconomic context of the intervention area (e.g. underlying gender norms, household investment priorities) can help design interventions with high impact that reach those who need it the most.

Furthermore, complementing the dissemination of aquaculture innovations with GTAs can possibly contribute to positive and long-lasting sustainability outcomes. Drawing from the lessons learnt from this study, some relevant activities might include:

- involve and empower all relevant local actors (e.g. men, women, community leaders) across multiple entry points (e.g. household level, community level, local formal and informal institutions);

- engage such actors in self-reflection exercises that best accommodate the intervention context (e.g. workshops, role play, drama plays, games), where cultural and socioeconomic barriers and restrictive gender norms can be identified, and their possible effect for the expected outcomes become clear;

- persuade each actor to takes responsibility of their role in challenging these cultural and socio-economic norms and overcome the barriers that could constrain the sustainability outcomes of the intervention. 


\section{Conclusion}

This study suggests that the intensification of small-scale aquaculture systems through ecosystem approaches that provide habitat to fish in underutilized ponds can have multiple positive sustainability impacts. In particular, these ecoponds are associated with higher fish productivity, fish species diversity, and income generation potential. Furthermore, the active involvement of women in their development and operation can have some women's empowerment benefits in terms of control of income and productive assets, which are very important in the sociocultural context of rural Bangladesh. Indeed engagement with ecoponds seems to generate greater confidence among women to take more initiative in fish aquaculture, rather than their usual role in downstream fish processing activities. In this case, women's access and active participation in homestead aquaculture increased their basic understanding on fish production technologies, and ability to utilize them effectively. However, despite its positive effect on some aspects of women's empowerment, the intervention did not affect wider gender inequality aspects and gender roles. Furthermore, the food security outcomes are rather inconclusive, possibly due to the lower prioritization of diversified diets in the context of household expenditures.

The above suggest that the intensification of small-scale aquaculture systems through ecosystem approaches can help achieve localized progress across multiple SDGs. However, there is a need to strengthen certain impact pathways to further improve food security and women's empowerment. While some can become parts of the intervention package (e.g. education about diversified diets and nutrition) others might reflect broader cultural and socioeconomic constraints that could be beyond the domain of a single intervention. The comparative effects of such mechanisms need to be understood better and to the extent approached through targeted GTAs to further ascertain the potential for upscaling such ecosystem approaches to small-scale aquaculture in Bangladesh and other similar developing contexts.

Supplementary Information The online version contains supplementary material available at https://doi.org/10.1007/s11625-021-01076-w.

Funding The ecopond projects (Ecopond I and II) were funded by the Innovation Fund of the Blue Gold Program of the Government of the Netherland and the CGIAR Research Program on Aquatic Agricultural System (AAS) led by WorldFish. The projects were implemented in collaboration with the Department of Fisheries (DoF), Bangladesh Water Development Board (BWDB) and initially in partnership with BRAC (during Ecopond I). The ecopond impact study was conducted with financial support from the CGIAR Research Program on Fish Agri-Food Systems (FISH) led by WorldFish. We acknowledged the support of the Blue Gold Program, AAS and FISH, DoF, BWDB, and BRAC.

\section{Declarations}

Conflict of interest The ecopond project intervention (Ecopond I and II) evaluated in this study was designed and implemented by WorldFish Bangladesh in collaboration with partners. Some of the co-authors in this study are affiliated with WorldFish.

Open Access This article is licensed under a Creative Commons Attribution 4.0 International License, which permits use, sharing, adaptation, distribution and reproduction in any medium or format, as long as you give appropriate credit to the original author(s) and the source, provide a link to the Creative Commons licence, and indicate if changes were made. The images or other third party material in this article are included in the article's Creative Commons licence, unless indicated otherwise in a credit line to the material. If material is not included in the article's Creative Commons licence and your intended use is not permitted by statutory regulation or exceeds the permitted use, you will need to obtain permission directly from the copyright holder. To view a copy of this licence, visit http://creativecommons.org/licenses/by/4.0/.

\section{References}

Ahmed M, Lorica MH (2002) Improving developing country food security through aquaculture development - Lessons from Asia. Food Policy 27:125-141. https://doi.org/10.1016/S0306-9192(02) 00007-6

Ahmed M, Halim S, Sultana S (2012) Participation of Women in Aquaculture in Three Coastal Districts of Bangladesh: Approaches Toward Sustainable Livelihood. World J Agric Sci 8:253-268

Ahmed A, Dompreh E, Gasparatos A (2019) Human wellbeing outcomes of involvement in industrial crop production: Evidence from sugarcane, oil palm and jatropha sites in Ghana. PLoS ONE 14:e0215433. https://doi.org/10.1371/journal.pone.0215433

Alexander P, Rounsevell MDA, Dislich C, Dodson JR, Engström K, Moran D (2015) Drivers for global agricultural land use change: The nexus of diet, population, yield and bioenergy. Glob Environ Chang 35:138-147. https://doi.org/10.1016/j.gloenvcha.2015.08. 011

Alkire S, Meinzen-dick R, Peterman A, Quisumbing AR, Seymour G, Vaz A (2013) Instructional guide on the women's empowerment in agriculture index. International Food Policy Research Institute (IFPRI), Washington DC

Amirkolaie AK (2011) Reduction in the environmental impact of waste discharged by fish farms through feed and feeding. Rev Aquac 3:19-26. https://doi.org/10.1111/j.1753-5131.2010.01040.x

Aregu L, Choudhury A, Rajaratnam S, Locke C, McDougall C (2018) Gender norms and agricultural innovation: insights from six villages in Bangladesh. J Sustain Dev 11:270. https://doi.org/10. 5539/jsd.v11n4p270

Aregu L, Choudhury A, Rajaratnam S, Van der Burg M, McDougall C (2019) Implications of agricultural innovation on gender norms: gender approaches in aquatic agriculture in Bangladesh. Gender, agriculture and agrarian transformations: changing relations in Africa, Latin America and Asia, pp.162-179

Azad AK, Jensen KR, Lin CK (2009) Coastal aquaculture development in Bangladesh: Unsustainable and sustainable experiences. Environ Manage 44:800-809. https://doi.org/10.1007/ s00267-009-9356-y

Belton B, Azad A (2012) The characteristics and status of pond aquaculture in Bangladesh. Aquaculture 358-359:196-204. https://doi. org/10.1016/j.aquaculture.2012.07.002

Belton B, Hossain MAR, Thilsted SH (2017) Labour, identity and wellbeing in Bangladesh's dried fish value chains. In: Johnson 
DS, Acott TG, Stacey N, Urquhart J (eds) Social Wellbeing and the Values of Small-scale Fisheries. Springer, Berlin, pp 217-241

Béné C, Barange M, Subasinghe R, Pinstrup-Andersen P, Merino G, Hemre GI, Williams M (2015) Feeding 9 billion by 2050 - Putting fish back on the menu. Food Secur 7:261-274. https://doi.org/10. 1007/s12571-015-0427-z

Béné C, Arthur R, Norbury H, Allison EH, Beveridge M, Bush S, Campling L, Leschen W, Little D, Squires D, Thilsted SH (2016) Contribution of fisheries and aquaculture to food security and poverty reduction: assessing the current evidence. World Dev 79:177-196

Beveridge MCM, Thilsted SH, Phillips MJ, Metian M, Troell M, Hall SJ (2013) Meeting the food and nutrition needs of the poor: The role of fish and the opportunities and challenges emerging from the rise of aquaculturea. J Fish Biol 83:1067-1084. https://doi. org/10.1111/jfb.12187

Belton B, Thilsted SH (2014) Fisheries in transition: Food and nutrition security implications for the global South. Global Food Security 3(1) 59-66. https://doi.org/10.1016/j.gfs.2013.10.001

Bogard JR, Hother A-L, Saha M et al (2015) Inclusion of small indigenous fish improves nutritional quality during the first 1000 days. Food Nutr Bull 36:276-289

Brugère C, Aguilar-Manjarrez J, Beveridge MCM, Soto D (2019) The ecosystem approach to aquaculture 10 years on - a critical review and consideration of its future role in blue growth. Rev Aquacult 11:493-514

Caliendo M, Kopeinig S (2005) Some practical guidance for the implementation of propensity score matching (No. 1588), IZA DP. Bonn

Cao Y, Li D (2013) Impact of increased demand for animal protein products in Asian countries: Implications on global food security. Anim Front 3:48-55. https://doi.org/10.2527/af.2013-0024

Choo PS, Williams MJ (2014) Avoiding pitfalls in development projects that aspire to empower women: A review of the Asian fisheries society gender and fisheries symposium papers. Asian Fish Sci 27S:15-31

Choudhury A, Castellanos P (2020) Empowering women through farmer field schools. Routledge Handbook of Gender and Agriculture.

Choudhury A, McDougall C, Rajaratnam S, Park CMY (2017) Women's empowerment in aquaculture: Two case studies from Bangladesh. Food and Agriculture Organisation (FAO), Rome; WorldFish, Penang

Chowdhury MAK (2009) Flexible, low input, production strategies and feed for inland coastal aquaculture of tilapia. WorldFish, Penang

Cole SM, Kaminski AM, McDougall C, Kefi AS, Marinda PA, Maliko M, Mtonga J (2020) Gender accommodative versus transformative approaches: a comparative assessment within a post-harvest fish loss reduction intervention. Gend Technol Dev 24(1):48-65

Diedrich A, Blythe J, Petersen E, Euriga E, Fatchiya A, Shimada T, Jones C (2019) Socio-economic drivers of adoption of smallscale aquaculture in Indonesia. Sustain 11:1-15. https://doi.org/ $10.3390 / \mathrm{su} 11061543$

DoF (2019) Fisheries resources survey system (FRSS), Department of fisheries, Bangladesh: ministry of fisheries and livestock. 36: 135p

Dompreh EB, Richard A, Alexandros G (2020) Do voluntary certification standards improve yields and wellbeing? Evidence from oil palm and cocoa smallholders in Ghana. Int J Agric Sustain. https://doi.org/10.1080/14735903.2020.1807893

Ellis T, Turnbull JF, Knowles TG et al (2016) Trends during development of Scottish salmon farming: An example of sustainable intensification? Aquaculture 458:82-99. https://doi.org/10.1016/j. aquaculture.2016.02.012

Eltholth M, Fornace K, Grace D, Rushton J, Häsler B (2015) Characterisation of production, marketing and consumption patterns of farmed tilapia in the Nile Delta of Egypt. Food Policy 51:131143. https://doi.org/10.1016/j.foodpol.2015.01.002
Engle CR, McNevin A, Racine P et al (2017) Economics of sustainable intensification of aquaculture: evidence from shrimp farms in vietnam and Thailand. J World Aquac Soc 48:227-239. https:// doi.org/10.1111/jwas. 12423

FAO (2010) Aquaculture Development. 4: Ecosystem Approach to Aquaculture. Food and Agriculture Organisation (FAO), Rome

FAO (2016) Promoting gender equality and women's empowerment in fisheries and aquaculture. Food and Agriculture Organisation (FAO), Rome

FAO (2017) Women's empowerment in aquaculture in Bangladesh and Indonesia: insights from four case studies: Insights from four case studies. Food and Agriculture Organisation (FAO), Rome

FAO (2020) The state of world fisheries and aquaculture. Food and Agriculture Organisation (FAO), Rome

FAOSTAT (2020) Food Balance Sheets. Food and Agriculture Organisation (FAO), Rome

Farnworth CR, Kantor P, Choudhury A, Mcguire S, Sultana N (2016) Gender relations and improved technologies in small household ponds in Bangladesh: rolling out novel learning approaches. Asian Fish Sci 29S:161-178

Farquhar SD, Khanal N, Shrestha M, Farthing M, Bhujel RC (2019) Socio-economic impacts of the Women in Aquaculture (WiA) project in Nepal. Kasetsart J Soc Sci 40:289-295. https://doi. org/10.1016/j.kjss.2017.12.014

Farris AR, Misyak S, O'Keefe K, VanSicklin L, Porton I (2020) Understanding the drivers of food choice and barriers to diet diversity in Madagascar. J Hunger Environ Nutr 15:388-400. https://doi.org/10.1080/19320248.2019.1566110

Frangoudes K, Gerrard S, Kleiber D (2019) Situated transformations of women and gender relations in small-scale fisheries and communities in a globalized world. Maritime Studies 18(3):241-248. https://doi.org/10.1007/s40152-019-00159-w

Ghose B (2014) Fisheries and aquaculture in Bangladesh: challenges and opportunities. Ann Aquac Res 1:1001

Gopal N, Williams MJ, Kyoko MP, Poh K, Choo S (2014) Gender in aquaculture and fisheries: navigating change. Asian Fisher Soc 27:1-14

Halim S, Ahmed MK (2006) Women in fisheries in Bangladesh: Level of involvement and scope for enhancement. Glob Symp Gend Fish 2000:159-168

Haque MM, Belton B, Alam M, Ahmed AG, Alam R (2016) Reuse of fish pond sediments as fertilizer for fodder grass production in Bangladesh: Potential for sustainable intensification and improved nutrition. Agr Ecosyst Environ 216:226-236

Harohau D, Blythe J, Sheaves M, Diedrich A (2020) Uneven adoption of tilapia aquaculture in rural Solomon Islands. Aquac Int 28:2093-2109. https://doi.org/10.1007/s10499-020-00577-2

Hartmann C, Siegrist M (2017) Consumer perception and behaviour regarding sustainable protein consumption: A systematic review. Trends Food Sci Technol 61:11-25. https://doi.org/10. 1016/j.tifs.2016.12.006

Henchion M, Hayes M, Mullen A, Fenelon M, Tiwari B (2017) Future protein supply and demand: strategies and factors influencing a sustainable equilibrium. Foods 6:53. https://doi.org/ $10.3390 /$ foods 6070053

Hendriks SL, Lyne MC (2003) Expenditure patterns and elasticities of rural households sampled in two communal areas of KwaZulu-Natal. Dev South Afr 20:105-127. https://doi.org/10.1080/ 0376835032000065516

Henriksson PJG, Tran N, Mohan CV, Chan CY, Rodriguez UP, Suri S, Mateos LD, Utomo NBP, Hall S, Phillips MJ (2017) Indonesian aquaculture futures: Evaluating environmental and socioeconomic potentials and limitations. J Clean Prod 162:1482-1490. https://doi.org/10.1016/j.jclepro.2017.06.133

Henriksson PJG, Belton B, Jahan K, Rico A (2018) Measuring the potential for sustainable intensification of aquaculture in 
Bangladesh using life cycle assessment. Proc Natl Acad Sci USA 115:2958-2963

Hernandez R, Belton B, Reardon T, Hu C, Zhang X, Ahmed A (2018) The "quiet revolution" in the aquaculture value chain in Bangladesh. Aquaculture 493:456-468. https://doi.org/10. 1016/j.aquaculture.2017.06.006

Hillenbrand E, Karim N, Mohanraj P, Wu D (2015) Measuring gender-transformative change: A review of literature and promising practices. CARE USA

Hossain MAR, Nahiduzzaman M, Sayeed MA, et al (2008) Fish consumption amongst poor people in Bangladesh: Effects of gender, location and wealth class. Aquac News, Bangladesh

Hossain MAR (2015) An overview of Fisheries sector of Bangladesh. Res Agric Livest Fish 1:109-126. https://doi.org/10.3329/ ralf.v1i1.22375

Hua K, Cobcroft JM, Cole A, Condon K, Jerry DR, Mangott A, Praeger C, Vucko MJ, Zeng C, Zenger K, Strugnell JM (2019) The future of aquatic protein: implications for protein sources in aquaculture diets. One Earth 1:316-329

Iacus SM, King G, Porro G (2009) CEM: Software for coarsened exact matching. J Stat Softw 30:1-27

ICSF (2010) Small Indigenous Freshwater Fish Species: Their Role in Poverty Alleviation, Food Security and Conservation of Biodiversity. International Collective in Support of Fishworkers (ICSF), Chennai

IPBES (2019) Global assessment report on biodiversity and ecosystem services. Intergovernmental Science-Policy Platform on Biodiversity and Ecosystem Services (IPBES) Secretariat, Bonn

Jahan KM, Ahmed M, Belton B (2010) The impacts of aquaculture development on food security: Lessons from Bangladesh. Aquac Res 41:481-495. https://doi.org/10.1111/j.1365-2109.2009. 02337.x

Jahan K, Belton B, Ali H, Dhar G, Ara I (2015) Aquaculture technologies in Bangladesh: An assessment of technical and economic performance and producer behavior. WorldFish, Dhaka

Joffre OM, Klerkx L, Khoa TND (2018) Aquaculture innovation system analysis of transition to sustainable intensification in shrimp farming. Agron Sustain Dev 38:34

Kabeer N (1999) Resources, agency, achievements: Reflections on the measurement of women's empowerment. Dev Chang 30(3):435-464

Kabir KA, Faruque G, Sarwar R, Barman B, Choudhury A, Hossain M, Hossain E, Aleem NA, Karim K, Phillips M (2015) Producing fish in small shaded homestead ponds: finding solutions with rural women. In: Humphreys E, Tuong TP, Buisson MC, Pukinsis I, Phillips M (Eds.), Revitalizing the Ganges Coastal Zone: Turning Science into Policy and Practices. CGIAR Challenge Program on Water and Food, Colombo. p. 600

Kantor P, Morgan M, Choudhury A (2015) Amplifying outcomes by addressing inequality: the role of gender-transformative approaches in agricultural research for development. Gend Technol Dev 19:292-319. https://doi.org/10.1177/0971852415596863

Karim M, Ullah H, Castine S et al (2017) Carp-mola productivity and fish consumption in small-scale homestead aquaculture in Bangladesh. Aquacult Int 25:867-879. https://doi.org/10.1007/ s10499-016-0078-x

Kastner T, Rivas MJI, Koch W, Nonhebel S (2012) Global changes in diets and the consequences for land requirements for food. Proc Natl Acad Sci USA 109:6868-6872. https://doi.org/10.1073/pnas. 1117054109

Kates RW (2011) What kind of a science is sustainability science? Proc Natl Acad Sci USA 108:19449-19450

Komiyama H, Takeuchi K (2006) Sustainability science: building a new discipline. Sustain Sci 1:1-6. https://doi.org/10.1007/ s11625-006-0007-4
Kruijssen F, McDougall CL, van Asseldonk IJM (2018) Gender and aquaculture value chains: A review of key issues and implications for research. Aquaculture 493:328-337. https://doi.org/10.1016/j. aquaculture.2017.12.038

Lau JD (2020) Three lessons for gender equity in biodiversity conservation. Conservation Biology 34(6) 1589-1591. https://doi.org/ 10.1111/cobi.13487

Lawless S, Cohen PJ, Mangubhai S, Kleiber D, Morrison TH (2021) Gender equality is diluted in commitments made to small-scale fisheries. World Development 140:105348. https://doi.org/10. 1016/j.worlddev.2020.105348

Lang DJ, Wiek A, Bergmann M, Stauffacher M, Martens P, Moll P, Swilling M, Thomas CJ (2012) Transdisciplinary research in sustainability science: practice, principles, and challenges. Sustain Sci 7:25-43. https://doi.org/10.1007/s11625-011-0149-x

Lee G, Suzuki A, Nam VH (2019) Effect of network-based targeting on the diffusion of good aquaculture practices among shrimp producers in Vietnam. World Development, 124, 104641

Manyungwa CL, Hara MM, Chimatiro SK (2019) Women's engagement in and outcomes from small-scale fisheries value chains in Malawi: effects of social relations. Maritime Studies 18(3):275285. https://doi.org/10.1007/s40152-019-00156-z

McDougall C (2017) Sustainable Intensification in Smallholder Agriculture. Routledge, London; New York: Routledge, 2017. I Series: Earthscan food and agriculture series

Merino G, Barange M, Blanchard JL, Harle J, Holmes R, Allen I, Allison EH, Badjeck MC, Dulvy NK, Holt J, Jennings S, Mullon C, Rodwell LD (2012) Can marine fisheries and aquaculture meet fish demand from a growing human population in a changing climate? Glob Environ Chang 22:795-806. https://doi.org/10.1016/j. gloenvcha.2012.03.003

Miyata S, Manatunge J (2004) Knowledge sharing and other decision factors influencing adoption of aquaculture in Indonesia. Int $\mathrm{J}$ Water Resour Dev 20:523-536. https://doi.org/10.1080/07900 620412331329162

Morgan M, Choudhury A, Braun M et al (2015) Understanding the gender dimensions of adopting climate-smart smallholder aquaculture innovations. Penang, Malaysia

Nabi R (2008) Constraints to the adoption of rice-fish farming by smallholders in Bangladesh: A farming systems analysis. Aquac Econ Manag 12:145-153. https://doi.org/10.1080/1365730080 2110844

Nam KC, Jo C, Lee M (2010) Meat products and consumption culture in the East. Meat Sci 86:95-102. https://doi.org/10.1016/j.meats ci.2010.04.026

Park CMY (2017) Women's empowerment in aquaculture in Bangladesh and Indonesia: Insights from four case studies. FAO, Rome

Petesch P, Bullock R (2018) Ladder of Power and Freedom: A qualitative data collection tool to understand local perceptions of agency and decision-making. GENNOVATE resources for scientists and research teams. CIMMYT, CDMX

Ross LG, Martinez Palacios CA, Morales EJ (2008) Developing native fish species for aquaculture: The interacting demands of biodiversity, sustainable aquaculture and livelihoods. Aquac Res 39:675-683. https://doi.org/10.1111/j.1365-2109.2008.01920.x

Shamsuzzaman MM, Islam MM, Tania NJ, Al-Mamun MA, Barman PP, Xu X (2017) Fisheries resources of Bangladesh: Present status and future direction. Aquacul Fisher 2:145-156

Shelly AB, D'Costa M (2001) Women in aquaculture: Initiatives of Caritas Bangladesh. Sixth Asian Fish. Forum Glob. Symp. Women Fish. 77-87

Shirajee S, Salehin MM, Ahmed N (2010) The changing face of women for small-scale aquaculture development in rural Bangladesh. Aquac Asia Mag 15:9-16

Siddiqua A, Haque SMB (2017) Women's Participation in Aquaculture in Southwest Bangladesh. Gender in Aquaculture and Fisheries: 
Engendering Security in Fisheries and Aquaculture. Asian Fish Sci 30S:375-381

Subasinghe R, Soto D, Jia J (2009) Global aquaculture and its role in sustainable development. Rev Aquac 1:2-9. https://doi.org/10. 1111/j.1753-5131.2008.01002.x

Thilsted SH, Thorne-Lyman A, Webb P, Bogard JR, Subasinghe R, Phillips MJ, Allison EH (2016) Sustaining healthy diets: The role of capture fisheries and aquaculture for improving nutrition in the post-2015 era. Food Policy 61:126-131

Toufique KA, Belton B (2014) Is Aquaculture Pro-Poor? Empirical Evidence of Impacts on Fish Consumption in Bangladesh. World Dev 64:609-620. https://doi.org/10.1016/j.worlddev.2014.06.035

Weindl I, Popp A, Bodirsky BL, Rolinski S, Lotze-Campen H, Biewald A, Humpenöder F, Dietrich JP, Stevanović M (2017) Livestock and human use of land: Productivity trends and dietary choices as drivers of future land and carbon dynamics. Glob Planet Change 159:1-10. https://doi.org/10.1016/j.gloplacha.2017.10.002
WFP (2008) Food consumption analysis - calculation and use of the food consumption score in food security analysis, Technical Guidance Sheet. World Food Programme, Wshington DC. https://doi. org/10.1017/CBO9781107415324.004

Wong F, Vos A, Pyburn R, Newton J (2019) Implementing Gender Transformative Approaches in Agriculture, CGIAR Collaborative Platform for Gender Research, Nairobi

Worldfish (2017) A final report on fish production in Homestead Ponds by Women: A New Dimension of Adopting Fish Culture in Bangladesh. WorldFish, Dhaka

Publisher's Note Springer Nature remains neutral with regard to jurisdictional claims in published maps and institutional affiliations. 